\title{
Pengelolaan Tanah Wakaf Untuk PCM Turi Yang Produktif dan Berkemajuan
}

\author{
Agus Nugroho Setiawan*1, Ghoffar Ismail² \\ 1,2 Universitas Muhammadiyah Yogyakarta \\ 1Program Studi Agroteknologi, Fakultas Pertanian, Universitas Muhammadiyah Yogyakarta \\ 2Program Studi Pendidikan Agama Islam, Fakultas Agama Islam, Universitas Muhammadiyah Yogyakarta \\ *e-mail: agusns@umy.ac.id
}

\begin{abstract}
As in the other areas, the management of waqf land in PCM Turi, Sleman, DIY has not been optimal, even though it has great potential if managed properly. This is due to the knowledge, insight and skills of the PCM Turi in managing the waqf land into a productive garden and making the waqf land as a medium for da'wah is still limited. Therefore, a community service program was conducted with several methods including coordination, counseling, technology transfer, training, as well as mentoring and evaluation. The results of the community service program show that the community service program has been carried out well, with the establishment of productive fruit and vegetable gardens. PCM Turi gains knowledge and skills in managing waqf land into productive land, so that it can become a media for da'wah bil hal and become an example for the other PCMs in managing the waqf land
\end{abstract}

Keywords: Management, PCM Turi, Productive, Waqf Land

\begin{abstract}
Abstrak
Seperti halnya di daerah lainnya, pengelolaan tanah wakaf di PCM Turi, Sleman, DIY belum optimal, padahal mempunyai potensi yang besar jika dikelola dengan baik. Hal tersebut disebabkan oleh pengetahuan, wawasan dan keterampilan Pimpinan Cabang Muhammadiyah Turi dalam mengelola tanah wakaf menjadi kebun yang produktif dan menjadikan tanah wakaf sebagai media dakwah bil hal masih terbatas. Oleh karenanya dilakukan program pengabdian pada masyarakat dengan sasaran Pimpinan dan anggota Muhammadiyah Cabang Turi. Untuk mencapai tujuan, digunakan beberapa metode kegiatan meliputi koordinasi, penyuluhan, transfer teknologi, pelatihan, serta pendampingan dan monitoring evaluasi. Hasil program pengabdian pada masyarakat menunjukkan bahwa Program pengabdian pada masyarakat sudah terlaksana dengan baik, dengan terbangunnya kebun buah dan sayur yang produktif. PCM Turi mendapatkan pengetahuan, wawasan dan keterampilan dalam mengelola tanah wakaf menjadi lahan yang produktif, sehingga dapat menjadi media dakwah bil hal dan menjadi contoh bagi masyarakat dan PCM lain dalam mengelola tanah wakaf
\end{abstract}

Kata kunci: Berkemajuan, PCM Turi, Pengelolaan, Produktif, Tanah wakaf

\section{PENDAHULUAN}

Turi merupakan salah satu kecamatan yang ada di Kabupaten Sleman, Daerah Istimewa Yogyakarta, yang berada pada dataran menengah-tinggi di lereng selatan Gunung Merapi, dengan tanaman utama adalah padi dan salak pondoh. Di Kecamatan Turi terdapat berbagai organisasi sosial kemasyarakatan, salah satunya adalah Muhammadiyah yang merupakan gerakan Islam modernis yang melakukan kepeloporan pemurnian Islam didirikan oleh K.H. Ahmad Dahlan pada tahun 1912 (Anonim, 2019). Sebagai organisasi keagamaan, gerakan Muhammadiyah di Kecamatan Turi melakukan aktivitas utama dakwah amar ma'ruf nahi munkar dengan berbagai kegiatan pendidikan, ekonomi, dan pengkaderan.

Muhammadiyah Cabang Turi mendapat amanah dari jamaah untuk mengelola beberapa bidang tanah wakaf, baik yang berupa lahan kosong, pekarangan rumah, atau kebun yang kurang produktif. Seperti halnya di beberapa daerah lainnya, pengelolaan tanah wakaf di Muhammadiyah Cabang Turi juga belum optimal. Pengelolaan tanah wakaf seringkali belum optimal disebabkan oleh banyak faktor, antara lain belum meratanya pemahaman dan paradigma baru wakaf sesuai UU No 41 Th 2014 (Athoillah, 2014). Pemahaman kebanyakan masyarakat tentang tanah wakaf mengarah pada suatu benda yang tidak bergerak, misalnya wakaf tanah untuk pendidikan, wakaf 
berupa tanah dan bangunan, wakaf pohon jati, sumur, kuburan atau yang lain untuk diambil manfaatnya. Pemahaman inilah yang menjadi salah satu penyebab kurang optimalnya fungsi wakaf sebagai sarana pengembangan syiar Islam dan pemberdayaan umat Islam (Muslich, 2016).

Tanah wakaf yang dikelola Pimpinan Cabang Muhammadiyah Turi mempunyai potensi yang besar jika dikelola dengan baik. Tanah wakaf sebenarnya dapat dikembangkan untuk tanaman kayu seperti sengon atau jati, namun memerlukan waktu panen yang cukup lama lebih dari 5 atau 10 tahun (Hardiatmi, 2010; Susrusa dan Ardhana, 2010), atau untuk tanaman pangan seperti jagung atau kacangan namun terkendala perlu pengelolaan yang intensif dan kebutuhan air yang agak banyak (Sirait et al., 2020). dengan berbagai pertimbangan seperti kondisi tanah di daerah Turi yang subur karena abu vulkanik Gunung Merapi dan udara yang sejuk, tanah wakaf Muhammadiyah Cabang Turi potensial untuk dikembangkan menjadi kebun produktif yang dapat menghasilkan buah dan sayuran, yang pada masa sekarang ini semakin banyak dibutuhkan oleh masyarakat. Konsumsi buah dan sayuran masyarakat baru mencapai 180 g per kapita per hari, padahal standar WHO mencapai 400 g perkapita per hari (Liputan6.com, 2018). Hal ini menunjukkan bahwa peluang pengembangan tanaman buah dan sayuran masih sangat terbuka.

Peluang kebutuhan buah dan sayur yang tinggi perlu ditangkap oleh Persyarikatan Muhammadiyah antara lain dengan menjadikan tanah wakaf dari jamaah menjadi kebun yang produktif. Permasalahan yang ada adalah Muhammadiyah Cabang Turi belum mempunyai wawasan dan ketrampilan dalam memanfaatkan tanah wakaf untuk kebun buah dan sayur. Oleh karena itu, perlu adanya upaya meningkatkan wawasan dan ketrampilan bagi Pimpinan Cabang Muhammadiyah Turi agar mampu mengelola tanah wakaf dengan baik melalui program pengabdian pada masyarakat.

Program pengabdian pada masyarakat dilakukan dengan tujuan untuk meningkatkan kesadaran, pengetahuan, wawasan dan keterampilan Muhammadiyah Cabang Turi dalam mengelola tanah wakaf amanah dari jamaah menjadi produktif dengan membangun kebun buah dan sayuran yang berkelanjutan, dan menjadikan tanah wakaf Muhammadiyah Cabang Turi sebagai model pengelolaan tanah yang produktif dan sekaligus menjadi media dakwah bil hal untuk membangun masyarakat yang berkemajuan.

\section{METODE}

Untuk mencapai tujuan dan menghasilkan luaran sesuai permasalahan yang dihadapi, digunakan beberapa metode yang meliputi sosialisasi, penyuluhan, transfer teknologi, praktek pengelolaan lahan, pendampingan serta monitoring dan evaluasi (Gambar 1).

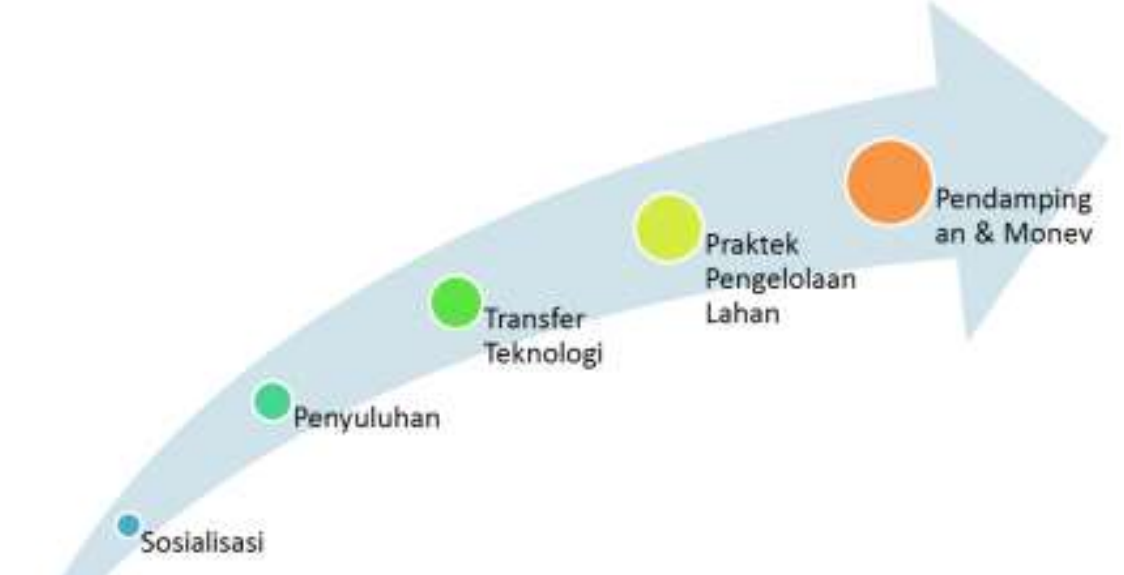

Gambar 1. Tahapan kegiatan pengabdian pada masyarakat 
Sosilaisasi dilakukan oleh Tim Pelaksana dengan tujuan menyampaikan gambaran tentang semua kegiatan dalam pengabdian pada masyarakat yang akan dilakukan. Penyuluhan dilakukan dengan mengumpulkan mitra sasaran untuk mengikuti penjelasan tentang pengelolaan tanah wakaf yang produktif, yang disampaikan oleh nara sumber yang kompeten di bidangnya dengan didampingi oleh Tim Pelaksana. Transfer teknologi dilakukan dengan pelatihan setelah penyuluhan untuk memberikan ketrampilan kepada mitra dalam mengelola tanah wakaf, yang dilakukan oleh trainer yang kompeten di bidang budidaya tanaman dengan didampingi oleh Tim Pelaksana. Praktek pengelolaan tanah wakaf dilakukan setelah penyuluhan dan transfer teknologi dengan dibimbing oleh Tim Pelaksana, yang dilanjutkan dengan pendampingan yang dilakukan secara periodik untuk membina dan mendampingi mitra sampai berhasil melakukan pengelolaan tanah wakaf sampai dicapai hasil yang optimal.

\section{HASIL DAN PEMBAHASAN}

Pengabdian pada masyarakat pengelolaan tanah wakaf di Pimpinan Cabang Muhammadiyah (PCM) Turi dilakukan selama 7 bulan mulai bulan Februari 2020 diawali dengan koordinasi baik secara internal oleh Tim pelaksana dosen dan mahasiswa, serta koordinasi eksternal antara Tim Pelaksana dengan PCM Turi. Koordinasi eksternal sebenarnya sudah mulai dilakukan pada bulan Februari 2020 (Gambar 2a) dan sudah disepakati tahapan dan jadual kegiatan yang akan dilakukan pada bulan Maret 2020. Namun karena terjadi pandemi Covid-19, kegiatan tidak dapat dilakukan sesuai jadual. Dengan mempertimbangkan waktu dan kondisi musim, dilakukan koordinasi kembali (Gambar 2b) dan disepakati jadual baru pelaksanaan kegiatan pengabdian pada masyarakat, yang akan dimulai bulan April 2020.

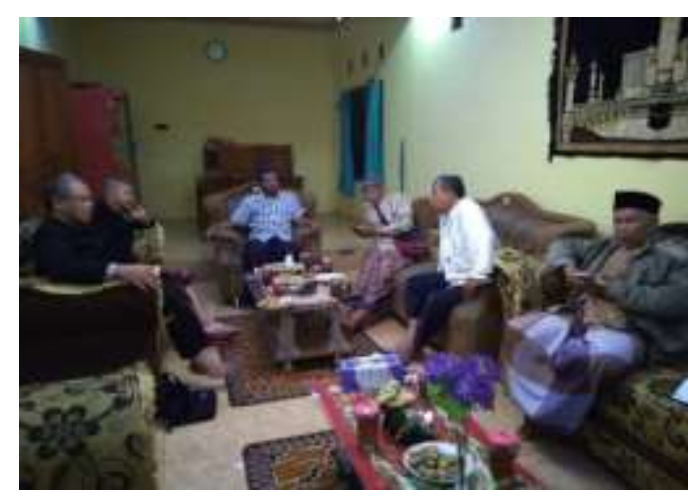

(a)

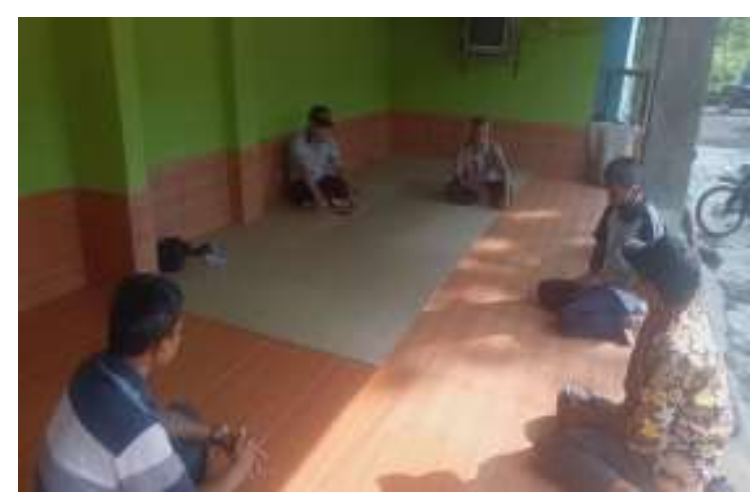

(b)

Gambar 2. Kegiatan Koordinasi \#1 - Februari 2020 (a) dan Koordinasi \#2 - April 2020 (b)

Setelah koordinasi, untuk mendapatkan kondisi terbaru tanah wakaf dilakukan survei bersama antara Tim Pelaksana dengan PCM Turi sebagai mitra (Gambar 3a). Dalam survei diperoleh informasi kondisi tanah wakaf yang banyak ditumbuhi oleh berbagai tanaman yang tidak produktif dan tidak terpelihara, serta tanah yang tidak rata (Gambar 3b). Selain itu juga didiskusikan tentang kemungkinan-kemungkinan yang dapat dilakukan untuk pengembangan tanah wakaf yang bermuara pada satu kesimpulan untuk mengelola tanah wakaf menjadi kebun buah dan sayuran yang produktif. 


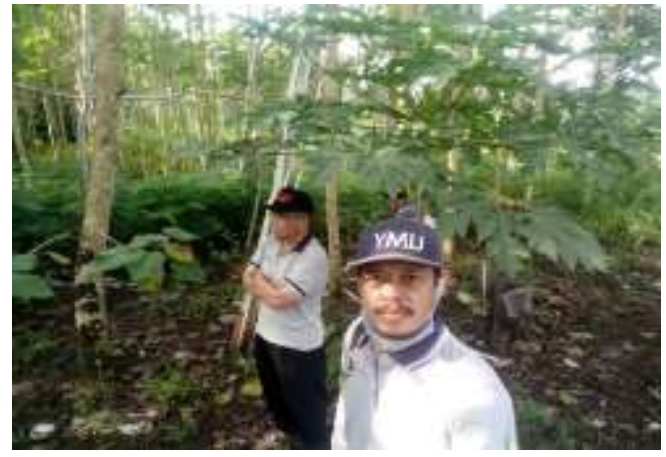

(a)

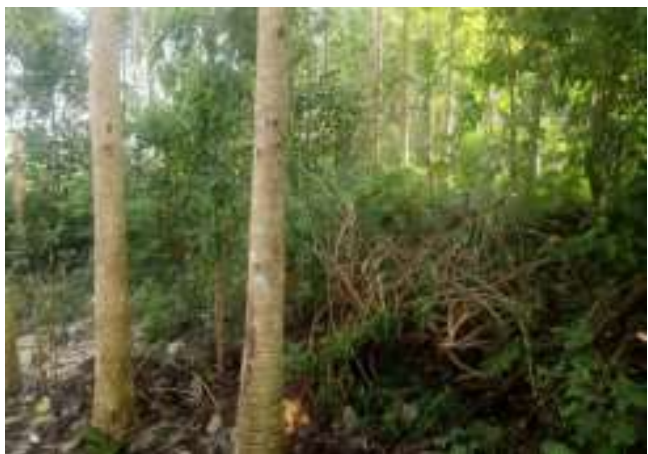

(b)

Gambar 3. Kegiatan Survei; Ketua Tim Pelaksana \& Ketua PCM (a) dan kondisi tanah wakaf (b)

Hasil survei lapangan selanjutnya digunakan sebagai dasar untuk kegiatan sosialisasi, yang dilakukan untuk memberikan gambaran umum tentang kegiatan pengabdian pada masyarakat, yang disampaikan oleh Tim Pelaksana (Gambar 4a) dengan dihadiri oleh segenap Pimpinan dan anggota PCM Turi (Gambar 4b). Pada kegiatan ini, Tim Pelaksana mengharapkan partisipasi aktif dan segenap anggota PCM Turi karena kemanfaatan dari pengabdian pada masyarakat akan dirasakan oleh persyarikatan dan jamaah Muhammadiyah. Setelah sosialisasi, dilakukan penyuluhan untuk memberikan pengetahuan dan wawasan tentang tanah wakaf, yang disampaikan oleh nara sumber dari Universitas Muhammadiyah Yogyakarta yang kompeten di bidangnya. Materi yang disampaikan adalah tanah wakaf sebagai amanah jamaah, budidaya tanaman, serta pengelolaan kebun buah dan sayuran. Karena masih dalam masa pandemi Covid19, kegiatan sosialisasi dan penyuluhan dilakukan dengan menerapkan protokol kesehatan seperti menjaga jarak, menggunakan masker, tidak saling berjabat tangan, menjaga kebersihan dengan memakai hand sanitizer (Menkes, 2020)

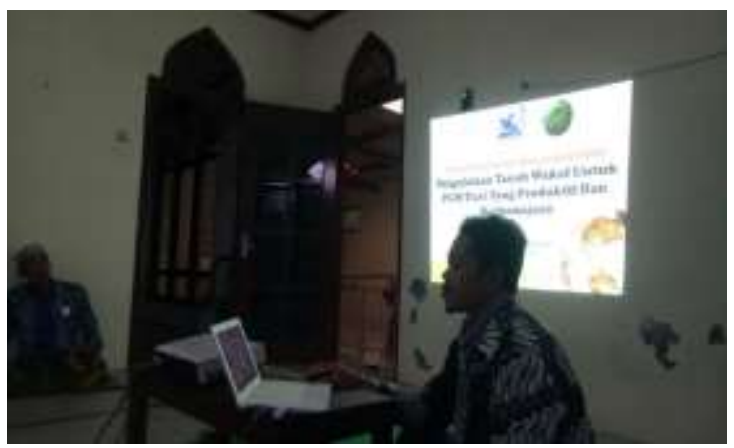

(a)

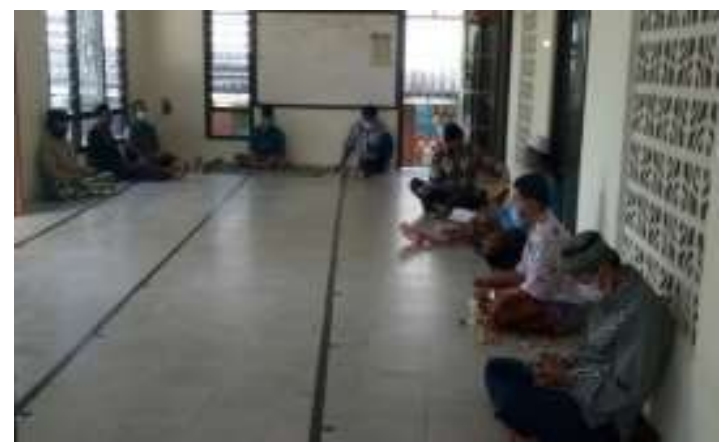

(b)

Gambar 4. Sosialisasi PPM oleh Tim Pelaksana (a) dan peserta penyuluhan di PCM Turi (b)

Langkah awal pelaksanaan pembangunan kebun buah dan sayuran Muhammadiyah adalah melakukan pembukaan lahan (land clearing). Semua tumbuhan yang ada, baik yang berupa pepohonan maupun semak dibersihkan dengan cara ditebang dengan prinsip pembukaan lahan tanpa bakar (PLTB). Batang dan cabang yang berupa kayu disingkirkan dari lahan, sedangkan sisa-sisa dedaunan dan ranting yang kecil dibiarkan berada di lahan (Gambar 5a) agar membusuk dan mengalami dekomposisi menjadi bahan organik sehingga dapat memperbaiki kesuburan tanah (Subowo, 2010). Setelah lahan terbuka, selanjutnya dilakukan pemetaan tanah untuk memastikan batas kepemilikan tanah wakaf.

Penyiapan lahan dilakukan dengan pengolahan tanah secara mekanik menggunakan bulldozer karena kondisi tanah yang cukup luas, tidak rata dan banyak bebatuan (Gambar $5 \mathrm{~b}$ ). Pengolahan tanah bertujuan membalik, menggemburkan, dan meratakan tanah, serta 
menyingkirkan bebatuan sehingga menjadi lahan tanam yang baik bagi budidaya tanaman (Nugroho, 2019).

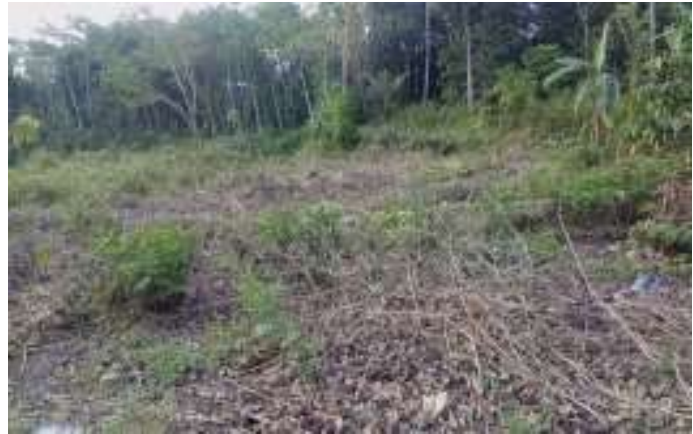

(a)

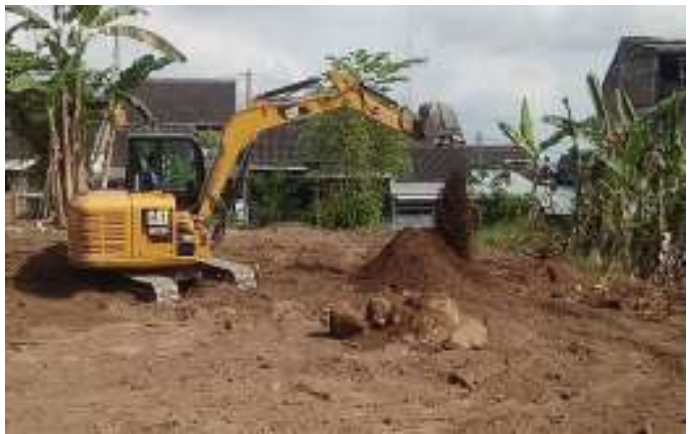

(b)

Gambar 5. Pembukaan lahan (a) dan pemetaan tanah wakaf (b)

Medium tanam yang baik adalah medium yang mampu menyediakan faktor pertumbuhan bagi tanaman terutama air, oksigen dan unsur hara sesuai dengan kebutuhan tanaman (Nugroho, 2019). Air merupakan sumberdaya alam yang sangat vital, sangat diperlukan dan menentukan keberlanjutan kehidupan (Mawardi, 2014) sehingga tanaman harus kecukupan air sesuai dengan jenis tanaman dan stadia pertumbuhannya. Selain itu, tanaman juga membutuhkan oksigen yang cukup untuk respirasi akar tanaman yang menghasilkan energi untuk pertumbuhannya, sehingga aerasi tanah tanah harus baik. Air dan oksigen di dalam tanah berada dalam keseimbangan karena air mengisi pori mikro tanah dan oksigen mengisi pori makro tanah. Jika tanah kering, tanaman akan kekurangan air namun kecukupan oksigen, dan sebaliknya pada tanah tergenang tanaman akan kecukupan air namun kekurangan oksigen (Wahjunie et al., 2008). Oleh karena itu, tanah harus mampu menyimpan air yang cukup namun tersedia dalam jumlah yang tidak berlebihan. Untuk memudahkan irigasi pada musim kemarau dan sekaligus mengurangi kelebihan air terutama pada musim hujan, dibuat parit irigasi/drainase melintang dan membujur lahan (Gambar 6a).

Tanah yang ada di kebun buah Muhammadiyah yang berada di lereng selatan Gunung Merapi berasal dari abu vulkanik dan didominasi oleh tanah muda (Regosol) dengan tekstur tanah yang kasar (pasiran) serta belum terbentuk struktur tanah yang baik dan bersifat granuler sehingga mudah kering (Utami et al., 2011), sehingga porositasnya tinggi dan kesuburan tanahnya rendah. Untuk membantu meningkatkan meningkatkan kemampuan tanah menyimpan air dan menambah unsur hara tanah diberikan pupuk organik sebagai pupuk dasar berupa pupuk kandang. Karena jarak antar lubang tanam untuk tanaman buah cukup lebar, maka pemberian pupuk kandang dilakukan hanya pada lubang tanam saja (Gambar 6b). Pupuk kandang yang digunakan adalah pupuk kandang sapi yang cukup banyak di wilayah Kecamatan Turi, yang dicirikan dengan warna yang sudah berubah menjadi hitam seperti tanah, tidak berbau, dan suhunya tidak tinggi (Trivana et al., 2017).

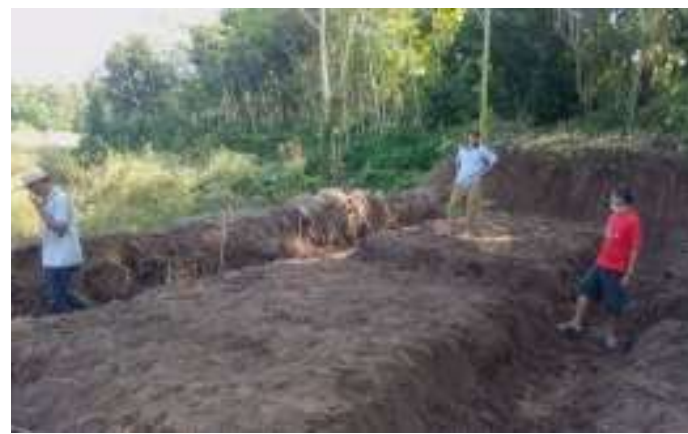

(a)

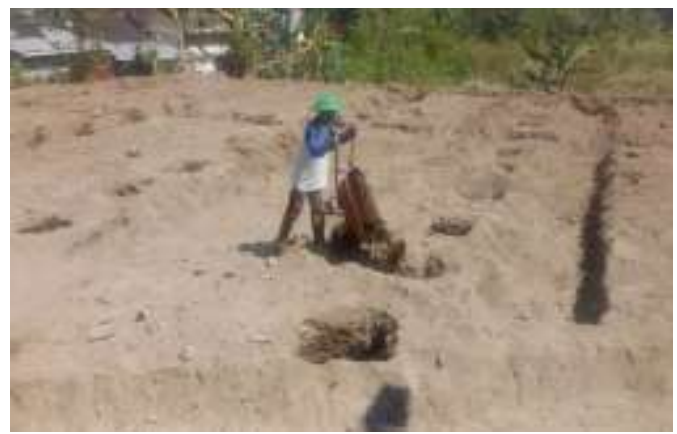

(b)

Gambar 6. Parit irigasi/drainase (a) dan pemberian pupuk kandang (b) 
Untuk membantu penyediaan air bagi tanaman di kebun buah dan sayuran terutama pada musim kemarau, dibuat jaringan irigasi dan bak penampung air. Jaringan irigasi dibuat dengan mengalirkan air menggunakan pipa pvc dari sumber air yang letak tempatnya lebih tinggi meskipun jaraknya ke kebun cukup jauh, agar kehilangan air akibat penguapan relatif kecil (Gambar 7a). Air dari sumber mata air yang dialirkan melalui pipa pvc, dimasukkan ke dalam bak penampung yang dibuat dari semen dengan ukuran 3,0 $\mathrm{m} \times 2,5 \mathrm{~m} \times 2,0 \mathrm{~m}$ sehingga mampu menampung air yang cukup banyak (Gambar 7b). Bak air dibuat pada bagian tanah yang lebih tinggi dari lahan penanaman sehingga air dapat dialirkan dari bak penampung ke lahan dan tanaman melalui pipa pvc dan selang plastik untuk menyiram tanaman.

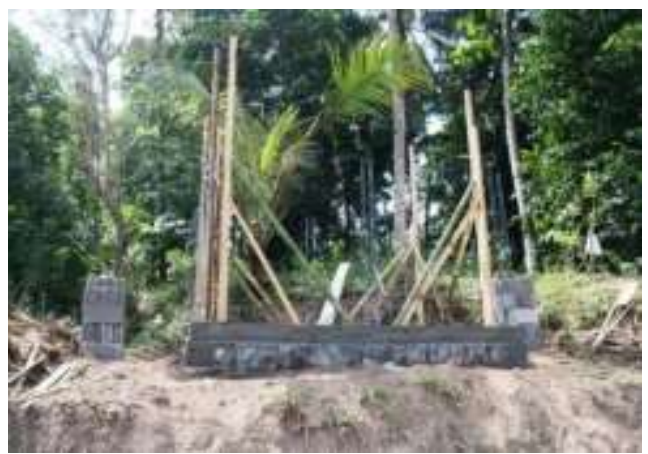

(a)

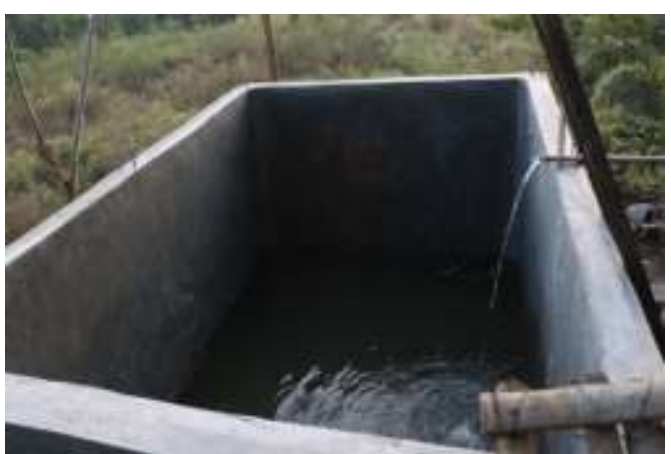

(b)

Gambar 7. Pengerjaan pembuatan bak penampung air (a) dan bak air sumber penyiraman (b)

Sambil mempersiapkan lahan dan bak penampung air, dilakukan pengadaan bibit tanaman. Jenis tanaman buah yang dipilih adalah durian, kelengkeng dan alpukat karena selain memang cocok ditanam di daerah Turi, juga karena digemari masyarakat dan mempunyai nilai ekonomi yang tinggi (Gambar 8a). Bibit durian dipilih klon Musang King, Bawor dan Duri Hitam yang termasuk durian unggul, rasanya sangat digemari masyarakat dan hasilnya tinggi (hot.liputan6.com, 2020). Kelengkeng dipilih klon Itoh yang terkenal karena buahnya yang manis, cepat berbuah dan produktivitasnya tinggi (Daryono et al., 2015), sedangkan alpukat yang dipilih adalah klon Hana-1 hasil kultur jaringan yang produktivitasnya sangat tinggi dan masa panennya cepat (Lensabanyuwangi.com, 2018). Selain itu juga disiapkan bibit pepaya California yang ukuran buahnya tidak terlalu besar, namun rasanya enak dan umur panennya cepat (Ismawati, 2020) (Gambar 8b).

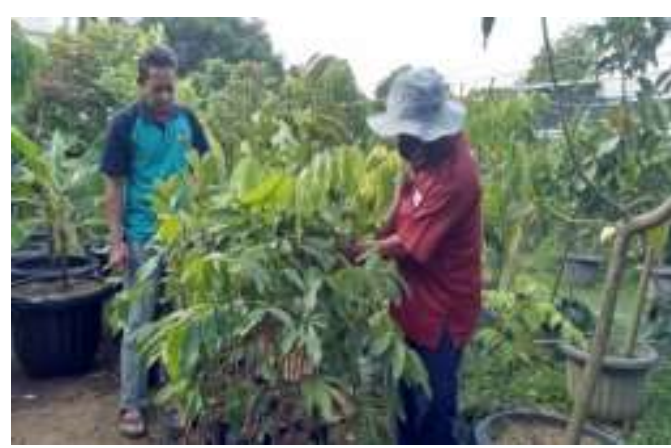

(a)

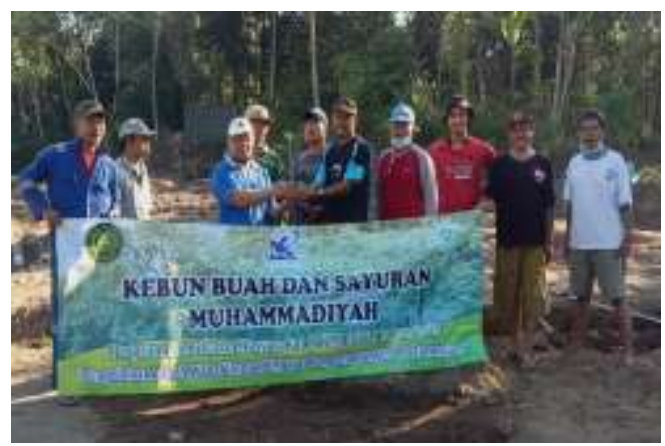

(b)

Gambar 8. Pengadaan bibit buah dari kebun bibit (a) dan serah terima bibit (b)

Penanaman dilakukan dengan terlebih dahulu diberikan demonstrasi tata cara penanaman yang baik oleh Tim Pelaksana, selanjutnya dilakukan penanaman bibit oleh Pimpinan dan anggota Cabang Muhammadiyah Turi dengan tetap dibimbing oleh Tim Pelaksana. Penanaman bibit dilakukan pada sore hari ketika intensitas sinar matahari dan suhu lingkungan sudah rendah, dengan cara membuka/menggali tanah yang sudah diisi dengan pupuk kandang seukuran 
polibag. Selanjutnya setelah polibag dibuka, bibit dimasukkan ke dalam lubang tanam dengan posisi tegak, dan ditutup tanah sampai penuh (Gambar 9a). Untuk memberikan kondisi media tanam yang kondusif bagi bibit, setelah penanaman dilakukan pemberian air (Gambar 9a). Hal ini dilakukan agar bibit tidak mengalami stres kekurangan air karena bibit yang masih berumur muda peka terhadap kondisi lingkungan terutama suhu tinggi dan kehilangan air.

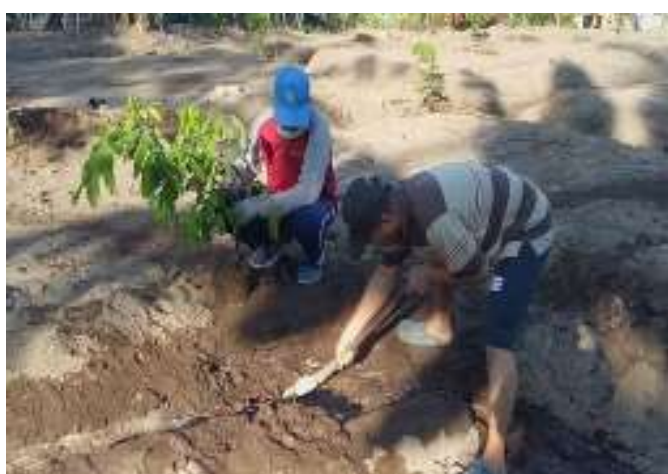

(a)

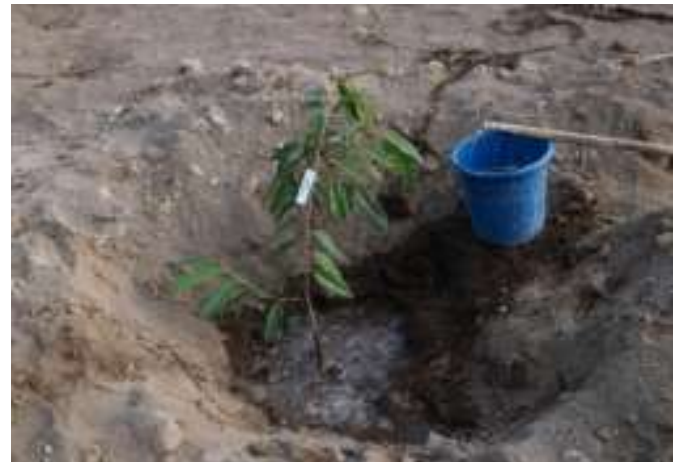

(b)

Gambar 9. Penanaman bibit buah (a) dan penyiraman setelah tanam (b)

Setelah penanaman, pemeliharaan tanaman perlu dilakukan dengan tujuan untuk memberikan kondisi lingkungan yang kondusif bagi tanaman. Pemeliharaan tanam yang penting adalah penyiraman karena tanah di kebun buah Muhammadiyah Turi merupakan tanah yang didominasi oleh fraksi pasir sehingga porositasnya tinggi dan kemampuan menyimpan air rendah. Pemberian air dilakukan pada sore hari ketika intensitas sinar matahari dan suhu lingkungan sudah rendah. Air untuk penyiraman berasal dari bak penampung air yang dialirkan melalui pipa pvc dan selang plastik. Air diberikan dengan cara disiramkan sampai tanah cukup basah (Gambar 10a).

Pemeliharaan yang lain adalah pemberian naungan untuk mengurangi intensitas sinar matahari yang sampai pada bibit. Meskipun tanaman buah yang diusahakan termasuk tanaman yang tahan terhadap naungan, tetapi karena masih berumur muda (bibit) maka peka terhadap kondisi lingkungan yang ekstrim, sehingga perlu penaungan. Naungan yang diberikan berupa pelepah daun salak pondoh yang memang tersedia cukup banyak di wilayah Turi yang merupakan daerah pengembangan salak pondoh (Gambar 10b).

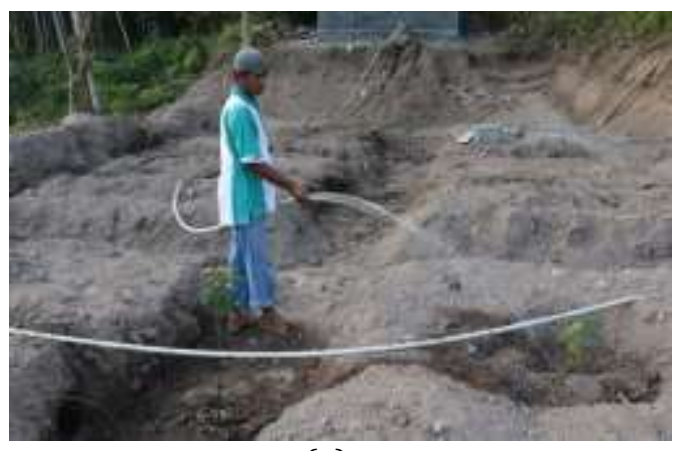

(a)

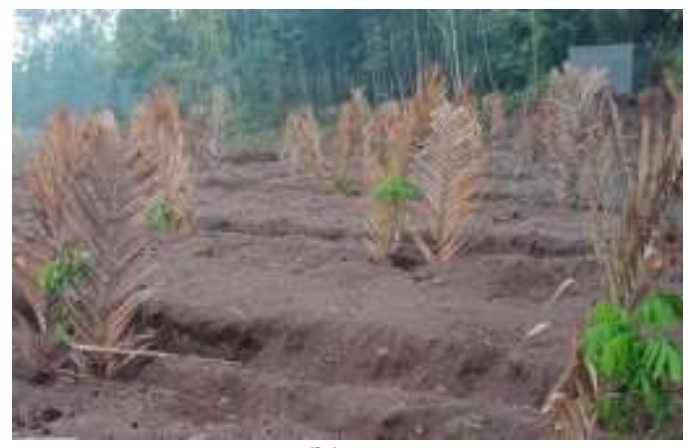

(b)

Gambar 10. Pemeliharaan tanaman dengan penyiraman (a) dan penaungan (b)

Untuk menjamin keberhasilan program pengabdian pada masyarakat membangun kebun buah dan sayur, dilakukan pendampingan oleh Tim Pelaksana. Pendampingan dilakukan dengan mengunjungi mitra secara periodik untuk pembinaan (Gambar 11a). Selain pembinaan secara rutin, juga dilakukan monitoring dan evaluasi bersama antara Tim Pelaksana dan PCM Turi (Gambar 11b). Evaluasi dilakukan terhadap jalannya program, dan jika ditemukan kondisi yang kurang sesuai dengan rencana, dilakukan perbaikan. 


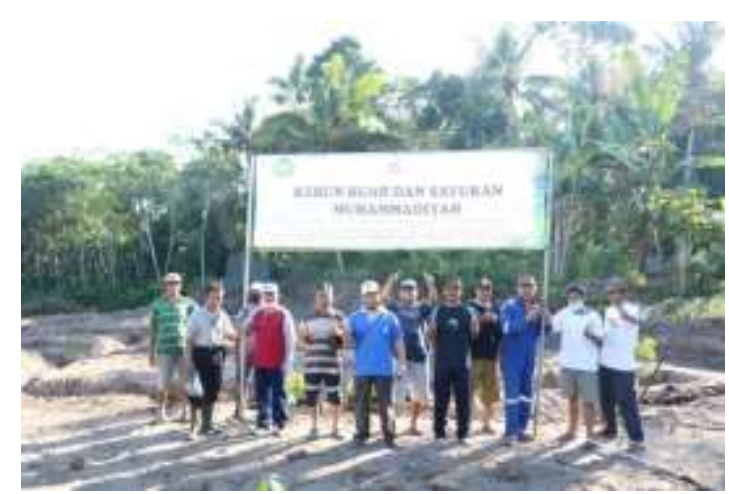

(a)

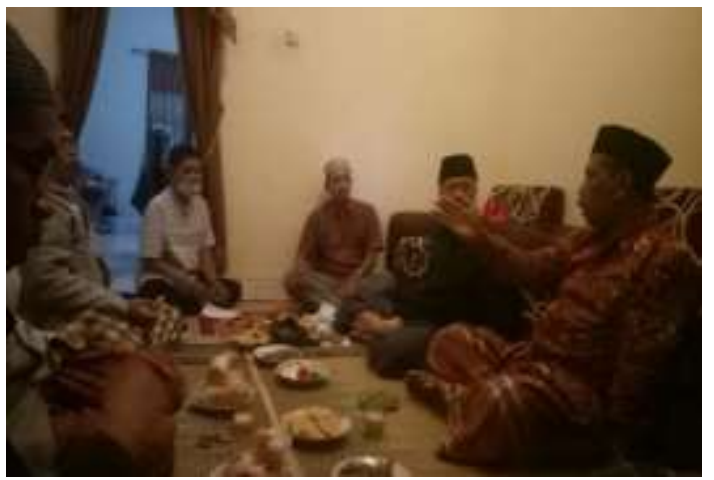

(b)

Gambar 11. Pendampingan pengelolaan kebun buah (a) dan evaluasi kegiatan PPM (b)

Program pengabdian pada masyarakat di PCM Turi sudah terlaksana dengan baik selama 7 bulan, dengan terbangunnya kebun buah dan sayur yang produktif (Gambar 12a). Untuk mencapai hasil yang maksimal dibutuhkan kemampuan dan kemauan dari Pimpinan dan anggota Muhammadiyah Cabang Turi, serta pendampingan yang intensif (Bande et al., 2020). Dari kegiatan yang sudah dilakukan, Pimpinan dan anggota Muhammadiyah Cabang Turi mendapatkan pengetahuan, wawasan dan keterampilan dalam mengelola tanah wakaf menjadi lahan yang produktif. Jika kebun sudah berproduksi dapat berperan sebagai sumber pemasukan bagi persyarikatan Muhammadiyah dalam berdakwah untuk mewujudkan masyarakat yang berkemajuan. Selain itu, kebun buah dan sayur dari tanah wakaf dapat menjadi media dakwah bil hal dan menjadi contoh bagi masyarakat dalam mengelola lahan, dan menjadi contoh bagi PCM lain dalam mengelola tanah wakaf. Dakwah amar ma'ruf nahi munkar tidak harus melalui pengajian atau di masjid saja, tetapi bisa dilakukan dengan memberi contoh bagi masyarakat bagaimana mengelola tanah wakaf yang baik dan produktif sehingga lebih bermanfaat. Untuk lebih mensosialisasikan keberadaan kebun buah dan sayur Muhammadiyah Turi dipasang papan petunjuk (Gambar 12b).

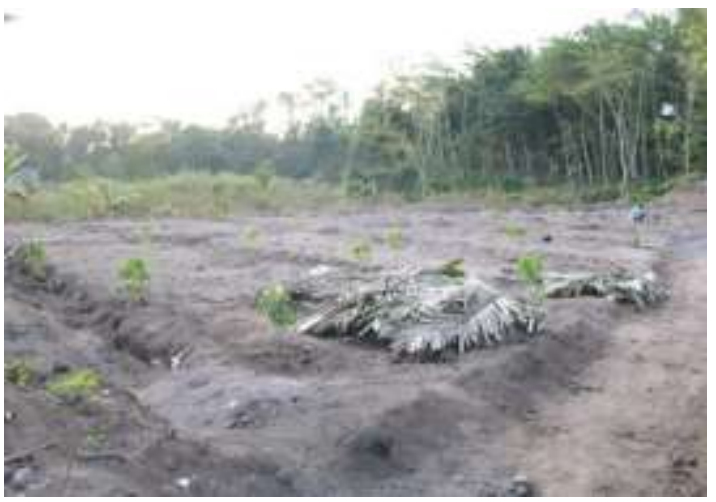

(a)

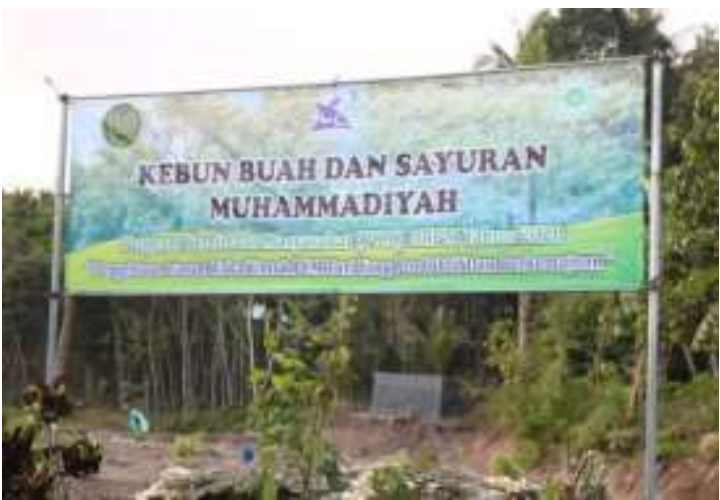

(b)

Gambar 12. Kondisi kebun buah (a) dan papan petunjuk kebun buah dan sayuran (b)

\section{KESIMPULAN}

- Program pengabdian pada masyarakat tentang Pengelolaan Tanah Wakaf di PCM Turi sudah terlaksana dengan baik, dengan terbangunnya kebun buah dan sayur yang produktif

- PCM Turi mendapatkan pengetahuan, wawasan dan keterampilan dalam mengelola tanah wakaf menjadi lahan yang produktif, sehingga dapat menjadi media dakwah bil hal dan menjadi contoh bagi masyarakat dan PCM lain dalam mengelola tanah wakaf 


\section{UCAPAN TERIMA KASIH}

Penghargaan dan ucapan terima kasih disampaikan kepada Direktur Riset dan Pengabdian Masyarakat Kementerian Riset dan Teknologi / Badan Riset dan Inovasi Nasional (DRPM Kemenristek/BRIN) yang telah menyediakan dana untuk mendukung kegiatan pengabdian pada masyarakat ini, Rektor dan Kepala LP3M UMY yang telah banyak mendukung kegiatan pengabdian pada masyarakat, mahasiswa UMY yang telah membantu pelaksanaan di lapangan, serta Pimpinan dan anggota Muhammadiyah Turi sebagai mitra yang telah berperan aktif dalam berbagai kegiatan, serta semua pihak yang telah berpartisipasi dalam pengabdian pada masyarakat ini.

\section{DAFTAR PUSTAKA}

Anonim. (2019). Struktur Organisasi. http://m.muhammadiyah.or.id/id/content-54-detstruktur-organisasi.html

Athoillah, M. (2014). Hukum Wakaf. Bandung. Rona Widya

Bande, L.O.S., Khaeruni R., A., Saefuddin, Haetami, A., Alwi, L., Mariadi \& Satrah, V.N. (2020). Pelatihan Pembuatan Pupuk Hayati, Agens Hayati dan Pestisida Nabati Desa Aunupe. Kabupaten Konawe Selatan. DINAMISIA : Jurnal Pengabdian Kepada Masyarakat. 4(1): 195200

Daryono, B.S., Rabbani, A. \& Purnomo. (2015). Aplikasi teknologi budidaya kelengkeng super Sleman di Padukuhan Gejayan. Bioedukasi. 9(1), 57-61

Hardiatmi, J.M.S. (2010). Investasi tanaman kayu sengon dalam wanatani cukup menjanjikan. Innofarm : Jurnal Inovasi Pertanian. 9(2), 17 - 21.

Hot.liputan6.com. (2020). 7 Jenis Durian Cepat Berbuah Terpopuler dan Banyak Digemari. Diunggah 20 Februari 2020. https://hot.liputan6.com/read/4183979/7-jenis-durian-cepatberbuah-terpopuler-dan-banyak-digemari

Ismawati, U. 2020. Pepaya California. Diakses 10 Agustus 2020. https://pertanian.pontianak kota.go.id/produk-unggulan-detil/5-pepaya-california.html

Lensabanyuwangi.com. (2018). Alpukat hana, alpukat lokal Indonesia, dipuja dan diburu. Diunggah 1 Oktober 2018. https://lensabanyuwangi.com/2018/10/01/alpukat-hanaalpukat-lokal-indonesia-dipuja-dan-diburu/

Liputan6.com. (2018). Konsumsi Sayuran dan Buah Masyarakat RI Masih di Bawah Standar FAO. Diunggah 24 April 2018. https://www.liputan6.com/bisnis/read/3483541/konsumsisayuran-dan-buah-masyarakat-ri-masih-di-bawah-standar-fao

Mawardi, M. (2014). Air dan masa depan kehidupan. Jurnal Tarjih. 12 (1), 131-141.

Menteri Kesehatan Republik Indonesia. (2020). Keputusan Menteri Kesehatan Republik Indonesia Nomor HK.01.07/MENKES/382/2020 tentang protokol kesehatan bagi masyarakat di tempat dan fasilitas umum dalam rangka pencegahan dan pengendalian corona virus disease $2019 \quad$ (Covid-19). $\quad$ http://hukor.kemkes.go.id/uploads/produk hukum/KMK No HK 01 07-MENKES-382-2020 ttg Protokol Kesehatan

Bagi Masyarakat di Tempat dan Fasilitas Umum Dalam Rangka Pencegahan Covid-19.pdf

Muslich, A. 2016. Peluang Dan Tantangan Dalam Pengelolaan Wakaf. MUADDIB. 06(02), 200-218

Nugroho, P.A. (2019). Pengolahan tanah dalam penyiapan lahan untuk tanaman karet. Perspektif. 17 (2), 129- 138.

Sirait, S., Aprilia, L. \& Fachruddin. (2020). Analisis neraca air dan kebutuhan air tanaman jagung (Zea mays L.) berdasarkan fase pertumbuhan di Kota Tarakan. Rona Teknik Pertanian. 13(1), $1-12$.

Subowo, G. (2010). Strategi efisiensi penggunaan bahan organik untuk kesuburan dan produktivitas tanah melalui pemberdayaan sumberdaya hayati tanah. Jurnal Sumberdaya Lahan. 4(1), 13-25.

Susrusa, K.B. dan Ardhana, I.P.G. (2010). Kelayakan finansial budidaya tanaman jati (Tectona grandis linn.) Varietas unggul di Kabupaten Buleleng. Soca. 10(2), 189-192 
Trivana, L., Pradhana, A.Y. \& Manambangtua, A.P. (2017). Optimalisasi waktu pengomposan pupuk kandang dari kotoran kambing dan debu sabut kelapa dengan bioaktivator EM4. Jurnal Sains dan Teknologi Lingkungan. 9(1), 16-24.

Utami, S.N.H., Maas, A., Darmanto, Jayadi, R., Martono, E., Purwanto, B.H., Kusumandari, A., Murdjito, G., Marwasta, D., Jamhari, dan Kastono, D. (2011). Pengelolaan Lahan Kawasan Lereng Merapi Pasca Erupsi 2010. Makalah Focus Group Discussion Peruntukan Lahan Produksi dan Konservasi Pasca Erupsi Merapi. Kantor BLH DIY, 4 Maret 2011.13 p.

Wahjunie, E.D., Haridjaja, O., Soedodo H. \& Sudarsono. 2008. Pergerakan air pada tanah dengan karakteristik pori berbeda dan pengaruhnya pada ketersediaan air bagi tanaman. Jurnal Tanah dan Iklim NO. 28. 15-26. 